\title{
INTERNATIONAL DIMENSION OF KNOWLEDGE MANAGEMENT IN SUPPLIER OF QUALITY OUTSOURCING - CASE STUDY
}

doi: $\quad 10.2478 /$ czoto-2019-0117

Date of submission of the article to the Editor: 05/12/2018

Date of acceptance of the article by the Editor: 27/01/2019

Agnieszka Puto ${ }^{1}$ - orcid id: 0000-0002-1947-0753

Mariusz Puto ${ }^{2}$ - orcid id: 0000-0001-9970-1824

${ }^{1}$ Czestochowa University of Technology - Poland, agnieszka.puto@wz.pcz.pl

${ }^{2}$ SGP - Outsourcing Company - Poland/Europe

Abstract: Currently, the conditions enterprises are operating in are marked by considerable instability. Thus the changes they may undergo are difficult to predict. Practitioners and theoreticians of management science point to various approaches to building competitive advantage. In the past few years, the focus has been put mainly on information and knowledge. According to advocates of the knowledge management concept, knowledge is of key importance to building competitive advantage and succeeding on the market. The issues of knowledge and how it is gathered, updated and applied are not new. The challenge for contemporary entrepreneurs is, however, how to manage knowledge in global enterprises. The aim of this study is to analyse the issue of knowledge management in a company which based its development on expansion into foreign markets. The research method applied is illustrative case study, the aim of which is to show how important knowledge management is for improving the efficiency of an internationalized enterprise.

Keywords: internationalization, outsourcing, development, knowledge, knowledge management

\section{INTRODUCTION}

For several decades, the world economy has been undergoing radical changes due to its accelerated globalization. This process was possible owing to relative political stability and wide use of the technological fruits of the IT revolution. The new conditions triggered an increased flow of services, goods, capital, technologies and information. The range and scope of operations performed by enterprises are expanding too, which leads to creation of ever closer links between individual countries. Competitive advantage can be attained mainly through marketing new products and implementing new technologies. What is extremely important for the growth of businesses and their competitiveness on the global market is the choice of 
appropriate management methods. Company management and its methods are crucially important issues in the globalized world. This article attempts to determine the effect implementation of a knowledge and information management system has on a modern Polish enterprise operating on foreign markets.

\section{EFFECT OF GLOBALIZATION ON MODERN BUSINESS MANAGEMENT}

As it has already been said, the global economy has been going through radical changes. The globalization caused the increased flow of technologies, information, services, goods and capital, including foreign investments. The scope of operations run by companies is expanding, which strengthens the relations between individual countries. This would not be possible without the relative political stability and achievements of the IT revolution. Globalization typically refers to the process by which different economies and societies become more closely integrated, and concurrent with increasing worldwide globalization (Nilson, 2010).

Companies operating in supranational settings are referred to as multinational enterprises. "Multinational enterprise is an enterprise or corporation that owns substantial resources and performs various business activities through a network of branches located in different countries and each branch form its business strategy, based on the different market characteristics (Cavusgil et al., 2008). A multinational company has its registered office in one country but operates in several countries.

Globalization forces enterprises to adapt to the changes referred to as global development trends. To a large extent, the changes occurring in the world economy shape the approach to management of modern enterprises. Wishing to gain competitive advantage and achieve the planned targets, companies must continuously respond to the changes that occur in their surroundings. This forces them to be more open to innovation, including innovation in the process of knowledge management.

Knowledge management is an effort to increase useful knowledge in the organization. It is a natural outgrowth of late twentieth century movements to make organizational management and operations more effective, of higher quality, and more responsive to constituents in a rapidly changing global environment (Mcinerney and Koenig, 2011). Knowledge management is a process by which organizations generate value from their intellectual and knowledge-based assets (Santosus and Surmcz, 2001). Generating value from such assets requires sharing them with employees, departments and even other companies, so that best practices are developed. Knowledge management practitioners claim that, in order to obtain the best value from a company's intellectual assets, knowledge must not only be shared but also used as a basis for cooperation (Dąbrowski et al., 2002).

D.J. Skyrme points out that knowledge management is "the explicit and systematic management of vital knowledge and its associated processes of creating, gathering, organizing, diffusion, use and exploitation, in pursuit of organizational objectives" (Skyrme, 1999). W.R. Bukovitz and R.L. Williams claim that knowledge management is a process used by an organization to generate wealth based on its intellectual or knowledge-based assets (Bukovitz and Williams, 1999). Knowledge management is also every process or practice of creating, acquiring, gaining and use of knowledge, as well as sharing that knowledge, regardless of its source, for the purpose of learning and improvement of the conditions within an organization (Armstrong, 2007). Knowledge management focuses on creating knowledge and skills typical of a given 
enterprise, gained through the processes of learning within the organization. Achieving success on such a competitive market depends on skillful knowledge management and, therefore, on the management of all the employees who constitute that knowledge base.

The concepts of data, information and knowledge are often treated as synonyms. This is an erroneous approach, for each of them has a different meaning. Gathering immense volumes of diverse data does not always guarantee obtaining the required information. Large bulks of data often make it difficult to find the right ones that will make up the information required at a given moment in time, the information that can give us the knowledge we need in a specific situation and time.

Knowledge management is a complex and never-ending process composed of numerous stages. In general, several main processes of knowledge management can be distinguished: 1) identification and acquisition, i.e. searching for the sources of knowledge and information, both internal and external; 2) creation and development, i.e. relying on the knowledge of organization members, exchanging information between them, learning, externalizing, joint problem solving; 3) gathering, i.e. storing, selecting and updating knowledge and information; 4) sharing and dissemination, i.e. transferring knowledge to organization members or outside.

According to the authors of the knowledge management concept, the most important process is knowledge development. No universal methods seem to have been developed in this area. Certainly, knowledge development would be impossible without personal involvement of people. Employees or members of an organization must be willing to develop their knowledge. Another requirement is that people be ensured appropriate conditions for development of knowledge and given access to the sources of knowledge. It is also important that employees be given more freedom and autonomy, their creativity be supported, and that they be allowed to search for new solutions.

An important factor in the process of knowledge development is externalization, i.e. a transformation of tacit knowledge into explicit knowledge. The former refers to human knowledge and intuition resulting from life and professional experience and predispositions. It is difficult to codify and transfer such knowledge, for example verbally (verbal or written instructions, notes, manuals, etc.). The ability to transform tacit knowledge of employees is the essence of knowledge management.

\section{THE ROLE OF IT SYSTEMS IN KNOWLEDGE MANAGEMENT}

The development of IT systems embraced also business management support technologies. IT tools provide significant support to knowledge management. The technological revolution allowed to overcome the crisis of post-industrial society. In order for that revolution to bring about the expected results, the use of available data must be easy and convenient. The development of IT gave birth to ERP (Enterprise Resource Planning) systems which facilitate business operations of numerous kinds. They are used by companies or groups of collaborating companies to support management. Particular elements of such systems are responsible not only for gathering but also processing data. The functions of ERP systems ensure optimization of all the resources and processes of an enterprise. Most of the system's applications feature modular construction, which allows for exchange of information within particular elements. 
Implementation of an ERP system is usually motivated by growth and willingness to improve efficiency and productivity. It is worth noting that implementation of ERP systems often forces companies to reconstruct their business processes or entire organizational structures. As emphasized by Oseni et al, an ERP system is a type of packaged application software that is capable of fully integrating and automating business processes across functional areas (Oseni et al., 2017). In addition, ERP systems are capable of centralising operational information so that it can be shared by an organisation's key functional systems, and to facilitate rapid decision making, cost reductions, and greater managerial control (Davenport et al., 2004; Galy and Sauceda, 2014; Klans et al., 2000).

Modern integrated IT systems have essentially changed the methods of gathering, storing, disseminating and use of business data (Sutton, 2006). This change of orientation in information processing has also affected accounting systems. S. Shang and P.B. Seddon enumerate the following benefits of ERP systems implementation (Shang and Seddon, 2002):

- operational benefits such as reduction of costs and cycle duration;

- improvement of efficiency, quality and customer service;

- management benefits such as better resources management, better planning and decision-making, improved productivity;

- strategic benefits, i.e. support of business development and cooperation, product diversification, building innovativeness, cost leadership and interface with the surroundings;

- IT infrastructure benefits, resulting in a higher flexibility of business processes;

- cost reduction, IT infrastructure development and organizational benefits such as change of work patterns, facilitation of organizational learning, reinforcement, development of a common and coherent vision of growth.

A schedule of IT system implementation must cover several important stages. They especially include:

- pre-implementation analysis - this is the most important stage, which involves identification of requirements that must be met by the system. At this stage, a document is prepared describing system operation after implementation;

- installation and configuration - software is installed on the server and work stations. This stage involves edition of authorizations held by administrators of individual modules;

- migration of data from previously used software;

- software add-ons and integration with other solutions;

- end-user trainings;

- go-live assistance;

- support of ongoing work based on a maintenance agreement.

Designing and implementing ERP systems plays an important role in improving management and gaining competitive advantage. Implementation of integrated systems requires that financial expenditure be increased and that organizational efforts be made to achieve the expected objective. 


\section{METHODOLOGY AND OBJECTIVES OF THE RESEARCH}

The application of the illustrative case study research method aims at showing the significance of knowledge management in increasing the efficiency of operations run by an internationalized enterprise. The case study is an effect of one of the authors' participant observation in large several months long implementation of an ERP system.

One drawback of the selected method may be the author's lack of completely objective perspective. However, this may also be considered a starting point for further research and comparison. The observation covered a period of over two years, and started in September 2016. The observation was based on reports developed for the purposes of the ERP system implementation, and opinions obtained through interviewing the employees.

\section{SGP OUTSOURCING COMPANY CASE STUDY}

The object of observation is SGP - Sorting Group Poland sp. z 0.0., which is the leading supplier of solutions in the areas of selection and repair of parts, components and finished products for enterprises from the automotive, home electronics, household appliances and FMCG industries. As the parent company of SGP Group, it coordinates and supervises the operations of individual member companies. SGP is a group of domestic and foreign companies providing quality outsourcing services. The Group comprises 14 entities, including the aforementioned parent company. The entire Group employs nearly 500 staff on the basis of employment contracts, and several thousand people based on contracts of mandate (civil law contracts). The company's growth is reflected by its turnover which has increased five thousand-fold since 2006 (date of establishment). In the third quarter of 2018, the Group had a turnover of 23 million euros.

The main reasons for implementing an ERP system in the analysed company were its rapid growth and insufficient IT solutions. Taking into account the international range of operations and the complexity of projects carried out by the company, the implementation of the system was necessary also due to ineffective communication and knowledge management, both inside and outside the company.

The management board set the following objectives for the new system: 1) improvement of communication between organizational units; 2) improvement of the quality of data used in the decision-making process; 3) improvement of competitiveness; 4) improvement of cash flow; 5) cost reduction; 6) better work of administration; 7) centralization of main functions; 8) improvement of financial controlling in subsidiaries. The main rationale behind the new ERP system implementation was to improve the efficiency of the company's operations. This was possible owing to the integration of ERP modules, which allowed for a coherent consolidation of different sources of information (finances, distribution, purchases).

The implementation of the system started in 2016. In the second half of that year, an analysis of all the departments responsible for key operations was carried out. The following departments were selected as the most important: HR, Accounting, Purchase, Sales, Reporting and Controlling (which formed the basis for building modules under the same names). At the initial stage of the implementation, meetings were held in order to perform a detailed analysis of the information flow in the company. Each process was broken down step by step. Additionally, processes which were in no way systemically performed at that time (such as information flow in 
internal e-mail correspondence, data posted on the Intranet) were described. As a result of the meetings, an extensive document was prepared, describing individual departments and processes within them, as well as the responsible employees who later became the administrators of individual modules.

In December 2016, a contract was concluded with an implementing company. It was extremely important to choose a trustworthy partner. One of the first documents signed was a confidentiality agreement.

In the first half of 2017, a system description was prepared together with the consultants from the implementing company. The system is composed of two subsystems. The first subsystem is a classic ERP software, i.e. SIMPLE ERP. It is a basis where salaries are calculated, books are kept (chart of accounts, etc.) and sales invoices are issued. The other subsystem is XPRIMER, which is not a classic application installed on the hardware, but uses a web browser instead. This choice was dictated by the dispersed nature of the company's operations. Cooperation with coordinators scattered all over the world forced an unconventional approach to the system. They "feed" the system by entering the working time of quality inspectors in plants. They also upload cost documents. All that data is recorded in the aforementioned SIMPLE.ERP system, where accounts are assigned and working hours are posted to rotas and payrolls. Depending on the position of an employee, (coordinator, regional manager), the system has ready-made views, forms and grids, which allow for graphic entry of the required data into the system.

Table 1

SWOT analysis of the implemented ERP system

\begin{tabular}{|c|c|}
\hline Opportunities & Threats \\
\hline $\begin{array}{ll}- & \text { customer satisfaction } \\
- & \text { central control on workflow data } \\
- & \text { new strategies for improvement } \\
- & \text { division for consulting } \\
- & \text { market of software providers }\end{array}$ & $\begin{array}{ll}- & \text { security } \\
- & \text { cost of maintenance } \\
- & \text { slow development } \\
- & \text { lack of consultants trained in the field of } \\
& \text { ERP } \\
-\quad & \text { lack of qualified employees to operate } \\
& \text { and service the system }\end{array}$ \\
\hline Strengths & Weaknesses \\
\hline $\begin{array}{l}\text { - } \text { improvement of the customer service } \\
\text { process, } \\
\text { - } \text { re-engineering of the business } \\
\text { processes } \\
-\quad \text { optimization of the company's operating } \\
\text { costs } \\
-\quad \text { effective and experienced staff } \\
\text { responsible for the implementation } \\
-\quad \text { development of the long-term plans, } \\
\text { missions and visions of the organization } \\
-\quad \text { improvement of the efficiency of the } \\
\text { decision-making process } \\
-\quad \text { establishment of an organization with } \\
\text { one coherent decision-making pattern } \\
-\quad \text { establishment of a modern IT } \\
\text { infrastructure }\end{array}$ & 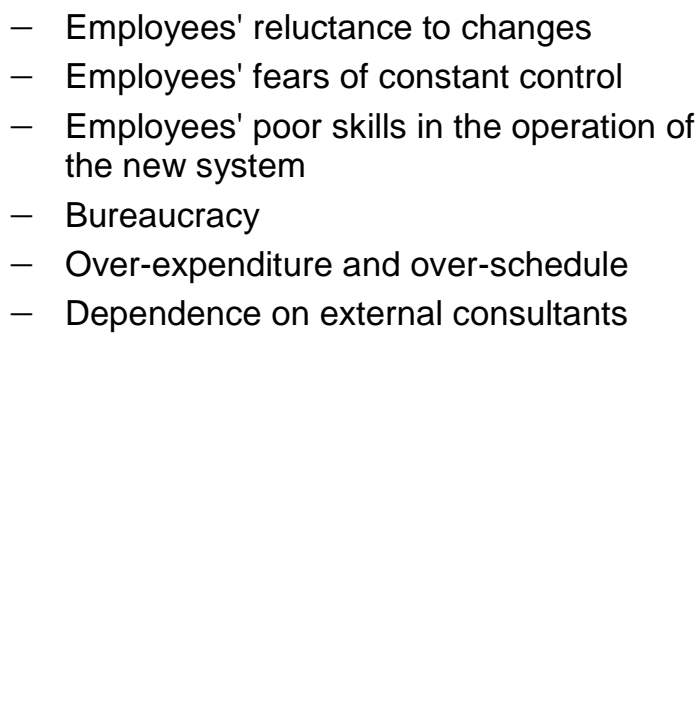 \\
\hline
\end{tabular}

Source: own work 
In the meantime, the data from the previous Comarch Optima system was being prepared for export to the new system. Entire documentation relative to the employees (the entire history since the company's foundation), contracts with customers, payroll data (e.g., for PIT purposes) was transferred. This stage was of critical importance for the entire project. Any discrepancies could result in penalties being imposed by state authorities, such as the Tax Office or the Social Insurance Institution.

The last stage of preparation involved an arduous training of the staff in the operation of the new system. Due to the dispersed nature of the operations, trainings were held at each branch in Poland (approximately 50 branches in large cities and on the premises of the company's clients). The new ERP system was launched in July 2017. After six months of transition, the system proved a success. In 2018, the implementation started in the foreign subsidiaries. The process was successful and the system was launched on schedule, though the budget was exceeded by $20 \%$. The anticipated cost of the system was $€ 600,000$.

The ERP system integrated all the cooperating modules, enabling data flow not only in Poland, but also in the foreign branches. What is more, its implementation allowed for the establishment of one common decision-making unit. The SWOT analysis presented below illustrates the results of the ERP system implementation in the examined enterprise (Table 1).

Implementation of such an integrated management system entailed re-engineering of certain business processes. It was used by SGP Group as an opportunity to build a centrally managed corporate network. The new system platform allowed for effective support of business processes within the Group and for increasing the efficiency of information and knowledge management. Thanks to centralization and integration of all areas of operation, the management board may now make strategic decisions more efficiently.

\section{CONCLUSION}

Management in companies operating on foreign markets entails a number of challenges regarding communication and knowledge management. One of the main functions of a knowledge management system is to supply its users with information which, once processed, allows for efficient decision making. Therefore, IT systems are a very important element of the knowledge management concept. However, their function is not to manage but only to support knowledge management within an organization. Internal and external changes of conditions that companies have to face motivate them to search for new solutions, including new technologies. The implementation of an ERP system in the analysed company was a consequence of the previously held intention and the rapid growth that required some changes. Despite the fact that the budget was exceeded, the discussed implementation is considered a success.

Discussing the issues of knowledge and information management in multinational enterprises, one should also bear in mind cultural differences and the necessity to adapt IT systems to different legal requirements and standards. The management board needs their data and information to be unified, but at the same time, local conditions impose certain standards. Due to its complexity, this issue was intentionally omitted from the article. Yet, it gives reason for further research into the subject. 


\section{References}

Armstrong, M., 2007. Zarządzanie zasobami ludzkimi. Oficyna Wolters Kluwer Business, Krakow.

Bukovitz, W.R., Williams, R.L., 1999. The Knowledge Management Fieldbook. Financial Times - Prentice Hall, Pearsons Education Ltd., London, 2.

Cavusgil, T., Knight, G., Riesenberger, J., 2008. International Business: Strategy, Management and the New Realities. Pearson Prentice Hall, Upper saddle River, New York.

Galy, E., Sauceda, M.J., 2014. Post-implementation practices of erp systems and their relationship to financial performance. Information \& Management, 51(3), 310319.

Davenport, T.H., Harris, J.G., Cantrell, S., 2004. Enterprise systems and ongoing process change. Business Process Management Journal, 10(1), 16 -26.

Dąbrowski, J., Koładkiewicz, I., Staniewski, M., 2002. Praktyki zarządzania wiedzą w przedsiębiorstwach funkcjonujących w Polsce [in:] Prace Naukowe Akademii Ekonomicznej we Wrocławiu, Stan i perspektywy rozwoju teorii i praktyki zarządzania na progu XXI wieku, 513-528

Frankel, J. 2006. What Do Economists Mean by Globalization? Implications for Inflation and Monetary Policy. Written for Academic Consultants Meeting, Board of Governors of the Federal Reserve System.

Gibson, K., 2009. BusinessDictionary. com, Reference Reviews, 23(2), 25-26, DOI: 10.1108/09504120910935183

Klans, H., Rosemann, M., Gable, G.G., 2000. What is ERP? Information System Frontiers, 2(2), 141-162.

Mcinerney, C.R., Koenig, M.E., 2011. Knowledge Management (KM) Processes in Organizations: Theoretical Foundations and Practice. Seires: Synthesis Lectures on Information Concepts Retrieval and Services, 3(1), Morgan \& Claypool Publishers, 1-2.

Nilson, T., 2010. Good for Living? On the Relationship between Globalization and Life Expectancy. World Development, 38(9), 1191-1203.

Oseni, T., Foster, S., Rahim, M., Smith, S.P., 2017. A framework for ERP postimplementation amendments: A literature analysis. Australasian Journal of Information Systems, 21, 1-21. DOI: 10.3127/ajis.v21i0.1268

Penc, J., 2002. Strategie zarządzania. Agencja Wydawnicza PLACET, Warszawa.

Santosus, M., Surmacz, J., 2001. The ABCs of knowledge management, 23 May, available at: www.cio.com/research/knowledge/edit/kmabcs.html

Shang, S., Seddon, P.B., 2002. Assessing and Managing the Benefits of Enterprise Systems. The Business Manager's Perspective. Information Systems Journal, 12(4).

Skryme, D.J., 1999. Knowledge Creation. Creating the Collaborative Enterprice. Butterworth - Heinemann, 39.

Sutton, S.G. 2006. Enterprise Systems and the Re-Shaping of Accounting Systems: $A$ Call for Research. International Journal of Accounting Information Systems, 7(1), 1.

Wawrzyniak, B., 2001. Od koncepcji do praktyki zarządzania wiedzą w przedsiębiorstwie. Zarządzanie wiedzą w przedsiębiorstwie. Materiały konferencyjne. Polska Fundacja Promocji Kadr - Zarząd, Warszawa. 